\title{
Analisis dan Pemodelan Inversi 3D Struktur Bawah Permukaan Daerah Panas Bumi Sipoholon Berdasarkan Data Gaya Berat
}

\author{
Jobit Parapat, Anik Hilyah, dan Widya Utama \\ Departemen Teknik Geofisika, Fakultas Teknik Sipil dan Perencanaan, Institut Teknologi Sepuluh Nopember (ITS) \\ e-mail:anik@geofisika.its.ac.id
}

\begin{abstract}
Abstrak-Daerah panas bumi Sipoholon merupakan salah satu daerah berpotensi panas bumi yang terletak di Kabupaten Tapanuli Utara, Propinsi Sumatera Utara, dan berada pada zona patahan Sumatera dengan manifestasi permukaan berupa mata air panas, bualan gas dan solfatar. Penelitian rinci metode gaya berat telah dilakukan di daerah ini pada tahun 2005. Sebanyak 230 data gaya berat telah diukur di daerah ini dengan cakupan luas pengukuran sekitar $14 \mathrm{~km}$ x $16 \mathrm{~km}$. Untuk melengkapi pemodelan 2D gaya berat terdahulu, maka penulis melakukan pemodelan 3D pada data gaya berat daerah ini. Studi ini bertujuan untuk mengetahui gambaran bawah permukaan berdasarkan distribusi densitas batuan secara tiga dimensi (3D). Hasil pemodelan berupa blok berdensitas rendah maupun tinggi diinterpretasikan dan dikorelasikan dengan informasi dan datadata geologi. Hasil pemodelan inversi 3D gaya berat ini memperlihatkan bahwa adanya blok batuan berdensitas tinggi dengan nilai antara $2,80-3,00 \mathrm{~g} / \mathrm{cm}^{3}$ yang berada di bagian selatan dan timur dengan kedalaman $>2 \mathrm{~km}$. Blok batuan ini diinterpretasikan sebagai tubuh batuan beku intrusif dan diduga berperan sebagai sumber panas dari sistem panas bumi Sipoholon. Selain itu, model juga menunjukkan adanya blok batuan berdensitas rendah nilai antara $2,00-2,30 \mathrm{gr} / \mathrm{cm}^{3}$ dekat permukaan dan di sekitar mata air panas daerah penelitian. Blok batuan ini diinterpretasikan sebagai batuan yang berasosiasi dengan rekahan membentuk zona patahan yang mengontrol manifestasi permukaan daerah Sipoholon.
\end{abstract}

Kata Kunci-Gaya Berat, Panas Bumi, Pemodelan 3d, Sumber Panas, Zona Patahan.

\section{PENDAHULUAN}

$\mathrm{D}$ AERAH Sipoholon, yang terletak di Kabupaten Tapanuli Utara, berdasarkan manifestasi permukaan panas bumi dan pola geologinya merupakan daerah yang berpotensi adanya sumber daya panas bumi. Namun, potensi ini belum dikembangkan untuk keperluan pembangkit tenaga listrik [1], karena belum adanya model konseptual sistem panas bumi daerah ini. Model konseptual adalah penggabungan model deskriptif maupun kualitatif yang menyatukan informasi fisik penting dari sistem panas bumi [2]. Model ini dihasilkan dari integrasi hasil penelitian geologi, geokimia, dan geofisika.

Daerah panas bumi Sipoholon sudah pernah diteliti dari segi geologi, geokimia, dan geofisika pada tahun 2005. Salah satu metode geofisika yang digunakan dalam penyelidikan potensi panas bumi di daerah Sipoholon ini adalah metode gaya berat. Penggunaan metode ini dalam eksplorasi panas bumi cukup efektif karena dapat mendelineasi struktur bawah permukaan [3] berupa zona patahan yang ditandai dengan kontras densitas rendah dan indikasi sumber panas yang ditandai dengan kontras densitas tinggi dengan batuan sekitarnya [4]. Hasil dari pengukuran ini perlu dimodelkan untuk mendapatkan persebaran densitas bawah permukaannya. Pemodelan gaya berat terdahulu yang pernah dilakukan di daerah ini masih menggunakan teknik pemodelan kedepan dua dimensi [5] sehingga belum sepenuhnya menggambarkan kondisi bawah permukaannya. Oleh karena itu, untuk melengkapi informasi tersebut, perlu adanya pemodelan inversi secara tiga dimensi (3D inversion modeling) terhadap data gaya berat yang sama, sehingga dihasilkan struktur bawah permukaan yang lebih akurat khususnya indikasi sumber panas dan zona patahan dari sistem panas bumi daerah Sipoholon ini. Hasil dari studi ini dapat digunakan sebagai informasi awal dalam pembuatan model konseptual sistem panas bumi daerah penelitian.

Lokasi daerah penelitian ini adalah daerah panas bumi Sipoholon yang secara administratif terletak di Kecamatan Sipoholon bagian tenggara dan Kecamantan Tarutung bagian utara, Kabupaten Tapanuli Utara, Provinsi Sumatera Utara. Daerah ini berjarak sekitar $280 \mathrm{~km}$ sebelah selatan Kota Medan dengan jarak tempuh 7 jam melalui jalur darat. Secara geografis, daerah ini terletak antara 98 $54^{\prime} 00^{\prime \prime}$ - 99 $01^{\prime} 30^{\prime \prime}$ BT dan $01^{\circ} 56^{\prime} 00^{\prime}$ ' LU sampai $02^{\circ} 06^{\prime} 00^{\prime \prime}$ LU atau antara $488000 \mathrm{mT}$ $504000 \mathrm{mT}$ dan 215600 - $232100 \mathrm{mU}$ pada sistem koordinat UTM zona 47 belahan bumi utara.

Daerah penelitian ini merupakan salah satu daerah berpotensi panas bumi yang sudah ditetapkan menjadi Wilayah Kerja Pertambangan (WKP) oleh Kementerian Energi dan Sumber Daya Energi Republik Indonesia. Namun sampai saat ini belum dimanfaatkan secara tidak langsung untuk pembangkit listrik. Hal ini diakibatkan karena masih perlunya penelitian lain yang lebih rinci untuk memastikan model konseptual sistem panas bumi daerah ini dan besarnya potensi energi yang bisa dibangkitkan. Daerah penyelidikan memiliki ukuran sekitar $14 \mathrm{~km}$ (ke arah timur) x $16 \mathrm{~km}$ (ke arah utara).

\section{METODE PENELITIAN}

Data yang digunakan dalam penelitian ini adalah data has il 
pengukuran metode gaya berat tahun 2005. Data gaya berat dihasilkan dari 230 titik stasiun pengukuran, dimana 7 lintasan berarah barat-timur (177 stasiun teratur) dan titik regional (53 stasiun acak) dengan spasi $250 \mathrm{~m}$ hingga $500 \mathrm{~m}$, yang tersebar di sekitar graben Tarutung. Data yang didapatkan kemudian direduksi dengan beberapa koreksi yang umum, termasuk koreksi medan (terrain), sehingga dihasilkan data anomali Bouguer. Kemudian data anomali Bouguer dipisahkan menggunakan metode second vertical derivative (SVD) dengan aplikasi filter Elkins, sehingga dihasilkan anomali residual (Gambar 1).

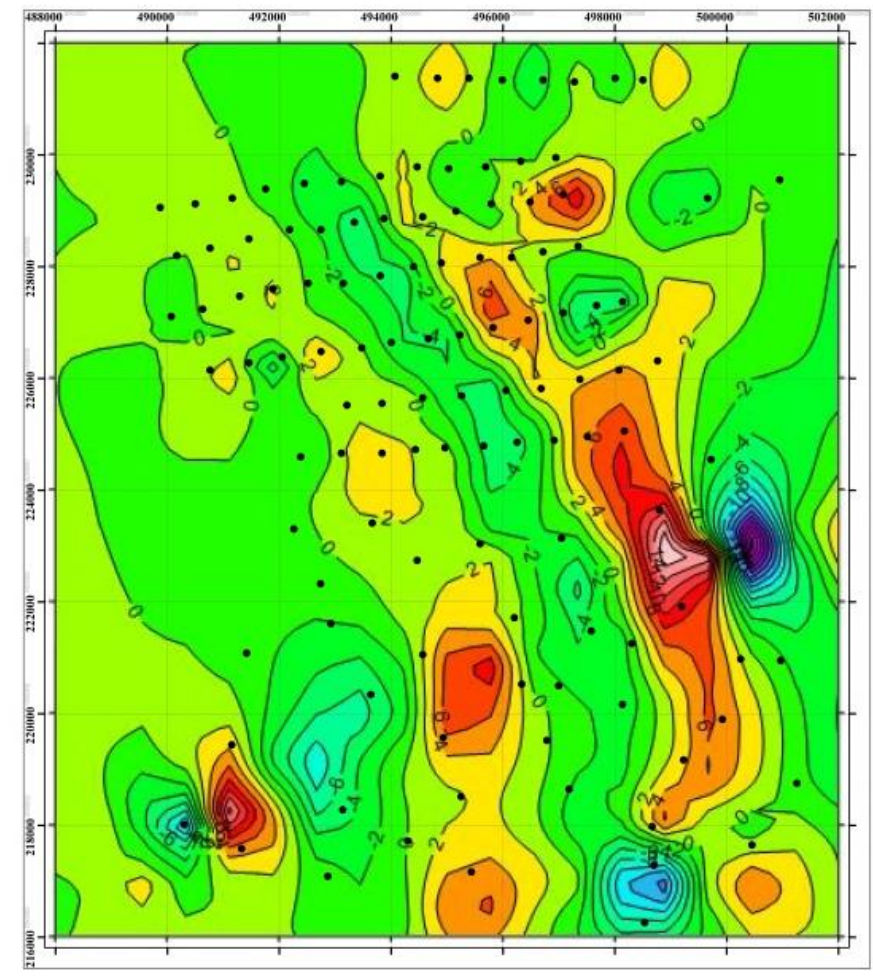

Gambar 1. Peta anomali residual

Pada penelitian ini, pemisahan anomali dilakukan menggunakan filter Second Vertical Derivative (SVD) dengan mengaplikasikan operator filter Elkins [6] yang ditampilkan pada Tabel 1. Dari proses pemisahan ini, output yang dihasilkan adalah data anomali residual. Kemudian anomali residual ini dimodelkan dengan teknik inversi untuk menghasilkan model sebaran densitas bawah permukaan daerah penelitian.

Pemodelan struktur bawah permukaan ini dilakukan dengan teknik inversi secara tiga dimensi (3D). Inversi 3D ini dilakukan dengan menggunakan perangkat lunak Grablox 1.6 sehingga menghasilkan model penampang densitas berbentuk 3D. Perangkat lunak ini menggabungkan dua metode inversi yaitu inversi Singular Value Decomposition (SVD) dan inversi Occam [7] yang diproses secara berurutan.

Inversi Singular Value Decomposition adalah suatu teknik penguraian suatu matriks ke dalam dua matriks [4], sebagai contoh dari matriks A menjadi matriks $U$ dan V. Secara matematis persamaannya [4] dapat ditulis sebagai:

$$
\mathrm{A}=\mathrm{U} \mathrm{S} \mathrm{V}^{\mathrm{T}}
$$

dimana $U$ adalah matriks ortogonal sebelah kiri, $S$ adalah suatu matriks diagonal, dan $V$ adalah matriks ortogonal sebelah kanan. Inversi Occam adalah suatu metode inversi yang memanfaatkan tingkat kekasaran model [8] yang secara matematis dapat ditulis:

$$
\mathrm{U}=\|\partial \mathrm{m}\|^{2}+\mu^{-1}\left\{\|\mathrm{Wd}-\mathrm{WGm}\|^{2}-\mathrm{X}^{2}\right\}
$$

dimana $\|\partial m\|^{2}$ merupakan kekasaran (roughness), $\mu^{-1}$ adalah Lagrange multiplier, $\|W d-W G m\|^{2}$ adalah missfit, dan $X^{2}$ adalah error.

Pemodelan inversi ini biasanya bersifat tidak unik atau tidak tunggal [9], artinya suatu respon anomali bisa dihasilkan oleh beberapa model bawah permukaan. Oleh karena itu, salah satu solusinya adalah penggunaan kedua metode inversi tersebut diatas. Integrasi kedua metode inversi tersebut mampu mengurangi dan menghasilkan nilai error (antara data observasi dengan data hasil perhitungan) yang lebih kecil, baik dari sisi nilai densitas maupun dimensinya melalui proses optimize, sehingga dihasilkan model densitas yang lebih akurat.

\section{HASIL DAN DISKUSI}

Model awal (Gambar 2) dibuat menggunakan perangkat lunak Grablox 1.6 dimana sumbu X dibagi menjadi 28 blok (nx), sumbu Y menjadi 32 blok (ny), dan sumbu $\mathrm{Z}$ menjadi 10 blok (nz) sehingga menghasilkan 8960 blok minor. Data anomali residual kemudian diinversikan terhadap model awal.

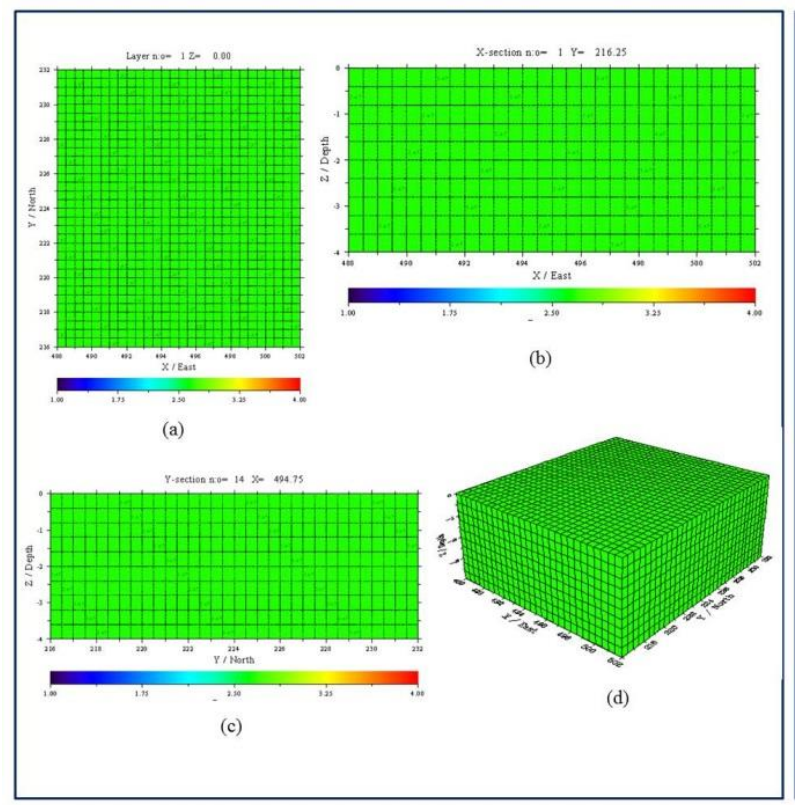

Gambar 2. Model awal yang digunakan

Proses inversi dilakukan dengan beberapa tahapan optimize yaitu dasar (Base), densitas (Density), densitas Occam (Occam d), ketinggian blok (Heights) dan ketinggian blok Occam 
(Occam h). Hasil akhir dari proses inversi akan menghasilkan model densitas tiga dimensi (3D).Hasil pemodelan 3D kemudian ditampilkan dalam bentuk sayatan penampang densitas 2D. Penampang model tersebut merupakan gambaran densitas batuan secara vertikal hasil sayatan model 3D. Pada penelitian ini, disajikan 5 (lima) penampang sayatan 2D dengan lintasan berarah barat-timur karena mempertimbang-kan struktur geologi berupa sesar yang ada sebagai pengontrol kemunculan manifestasi mata air panas di daerah penelitian.

Penampang model 2D lintasan A-A' yang terdapat pada $\mathrm{Y}=$ 216,75 ditunjukkan oleh Gambar 3. Berdasarkan pada peta geologi daerah panas bumi Sipoholon, sayatan penampang ini melintasi daerah Gunung Martimbang, satuan piroklastik Toba 1, satuan piroklastik Toba 2, dan juga Gunung Jorbing. Sayatan ini merupakan sayatan paling selatan dari daerah penelitian. Anomali maksimal pada sayatan ini bernilai sekitar $5 \mathrm{mgal}$. Kondisi ini dikarenakan oleh adanya massa batuan berdensitas tinggi (warna merah) dengan nilai $2,85-3,00 \mathrm{~g} / \mathrm{cm}^{3}$ pada koordinat X antara 492 sampai 497 dan mulai pada kedalaman $\mathrm{Z}>1 \mathrm{~km}$. Anomali negatif rendah bernilai sekitar $-7 \mathrm{mgal}$. Kondisi ini dikarenakan oleh adanya massa batuan berdensitas sangat rendah (warna biru tua hingga biru muda) dengan nilai $1,8-2,1 \mathrm{~g} / \mathrm{cm}^{3}$ pada koordinat $\mathrm{X}$ antara 498 sampai 499 yang dimulai dari permukaan hingga kedalaman $\mathrm{Z}$ sekitar $2 \mathrm{~km}$. Kemungkinan batuan ini diduga sebagai zona lemah dan merupakan produk dari proses deformasi. Jika kita bandingkan dengan kondisi geologi permukaannya, maka anomali rendah ini berada pada ujung graben Tarutung yang terbentuk akibat pertemuan 2 (dua) ujung sesar.

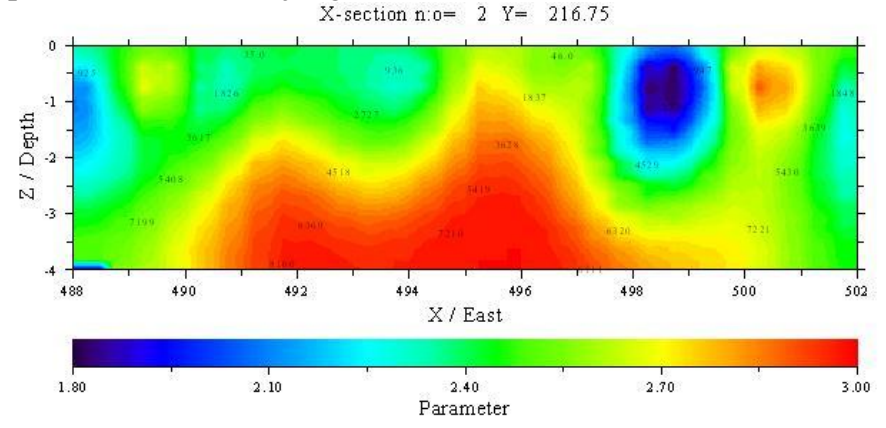

Gambar 3. Penampang model 2D lintasan A-A'

Penampang model 2D lintasan B-B' yang terdapat pada $\mathrm{Y}=$ 219,75 ditunjukkan oleh Gambar 4. Berdasarkan pada peta geologi daerah panas bumi Sipoholon, sayatan penampang ini melintasi daerah mata air panas Parbubu, satuan endapan aluvium, sinter karbonat, satuan piroklastik Toba 2, dan juga Gunung Jorbing. Anomali maksimal pada sayatan ini bernilai sekitar $8 \mathrm{mgal}$. Kondisi ini dikarenakan oleh adanya massa batuan berdensitas sedang (warna jingga) dengan nilai 2,75 $2,90 \mathrm{~g} / \mathrm{cm}^{3}$ yang tersebar dibawah permukaan membentuk pola penerobosan keatas dengan rata-rata pada kedalaman $1-1,5$ $\mathrm{km}$. Anomali negatif rendah bernilai sekitar $-4 \mathrm{mgal}$. Kondisi ini dikarenakan oleh adanya persebaran massa batuan berdensitas rendah (warna biru muda) dengan nilai $2,1-2,3 \mathrm{~g} / \mathrm{cm}^{3}$ di beberapa tempat. Salah satunya pada koordinat X antara 492 sampai 494 yang diduga sebagai patahan dan berperan sebagai pengontrol munculnya mata air panas Parbubu. Ada juga pada koordinat 498 sampai 499 dari permukaan hingga pada kedalaman $1,7 \mathrm{~km}$ yang diduga akibat respon dari sesar pembentuk graben Tarutung.

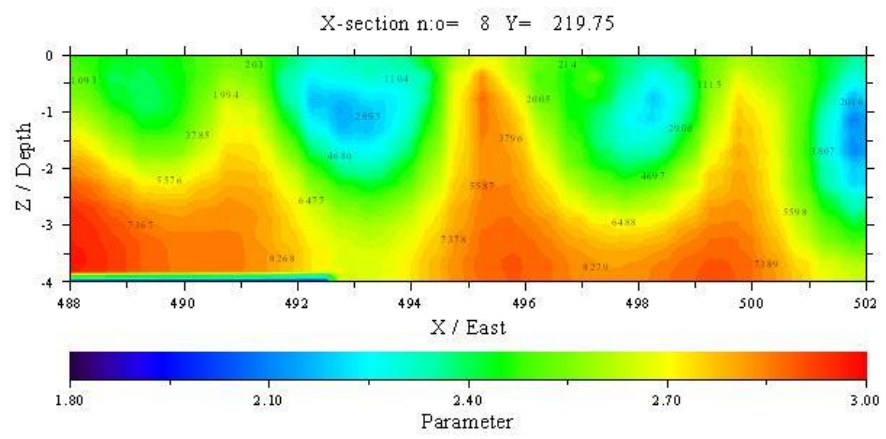

Gambar 4. Penampang model 2D lintasan B-B'

Penampang model 2D lintasan C-C' yang terdapat pada $\mathrm{Y}=$ 225,25 ditunjukkan oleh Gambar 5. Berdasarkan pada peta geologi daerah panas bumi Sipoholon, sayatan penampang ini melintasi Gunung Siborboron, satuan piroklastik Toba 2, satuan endapan aluvium, sinter karbonat, dan juga daerah mata air panas Hutabarat. Anomali maksimal pada sayatan ini bernilai sekitar 7,5 mgal. Kondisi ini dikarenakan oleh adanya massa batuan berdengan densitas tinggi (warna merah) dengan nilai $2,80-3,00 \mathrm{~g} / \mathrm{cm}^{3}$ pada koordinat $\mathrm{X}$ antara 488 sampai 490 dan pada kedalaman rata-rata $Z>2 \mathrm{~km}$ pada koordinat $X$ antara 497 sampai 502 dan pada kedalaman $Z>1,7 \mathrm{~km}$. Anomali negatif rendah bernilai sekitar -5 mgal. Kondisi ini dikarenakan oleh adanya massa batuan berdensitas rendah (warna biru muda) dengan nilai $2,12-2,3 \mathrm{~g} / \mathrm{cm}^{3}$ pada koordinat $\mathrm{X}$ antara 495 sampai 496,5 dari permukaan hingga kedalaman $1,5 \mathrm{~km}$. Massa batuan ini diduga sebagai batuan yang mengalami patahan sehingga berperan sebagai pengontrol munculnya mata air panas Hutabarat.

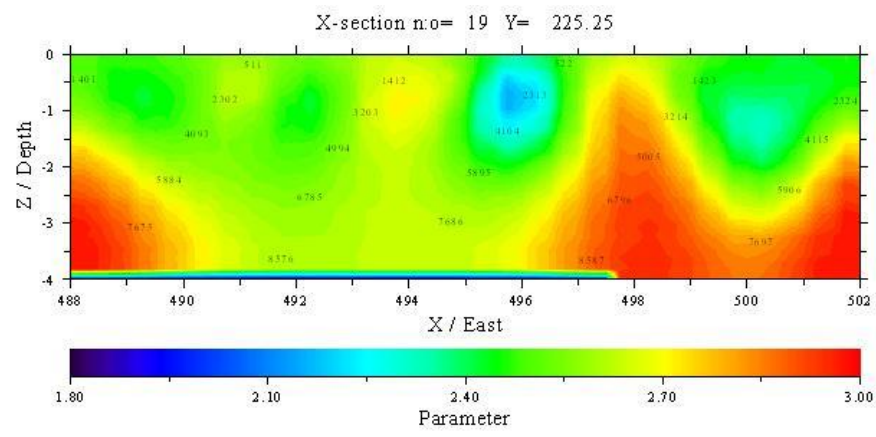

Gambar 5. Penampang model 2D lintasan C-C'

Penampang model 2D lintasan D-D' yang terdapat pada $\mathrm{Y}=$ 229,25 ditunjukkan oleh Gambar 6. Berdasarkan pada peta geologi daerah panas bumi Sipoholon, sayatan penampang ini melintasi daerah Gunung Palangkagading, satuan Piroklastik Toba, sinter karbonat, dan mata air panas Sipoholon. Anomali 
gravitasi maksimal pada sayatan ini bernilai sekitar $7 \mathrm{mgal}$. Kondisi ini dikarenakan oleh adanya massa batuan berdensitas sedang (warna jingga) dengan nilai $2,75-2,95 \mathrm{~g} / \mathrm{cm}^{3}$ pada koordinat $X=497$ dan kedalaman $Z=0,5 \mathrm{~km}$. Anomali negatif rendah bernilai sekitar -3 mgal. Kondisi ini dikarenakan oleh adanya massa batuan berdensitas rendah (warna biru muda) dengan nilai $2,15-2,3 \mathrm{~g} / \mathrm{cm}^{3}$ pada koordinat $\mathrm{X}=493$ dari permukaan hingga kedalaman $\mathrm{Z}=1,2 \mathrm{~km}$. Hal ini diduga sebagai respon dari sesar yang mengontrol munculnya mata air panas Sipoholon.

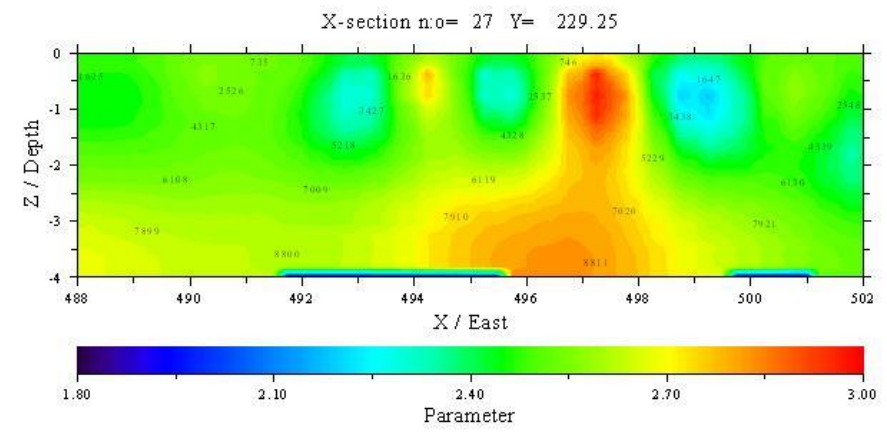

Gambar 6. Penampang model 2D lintasan D-D'

Penampang model 2D lintasan E-E' yang terdapat pada $\mathrm{Y}=$ 230,75 ditunjukkan oleh Gambar 7. Berdasarkan pada peta geologi daerah panas bumi Sipoholon, sayatan penampang ini melintasi daerah Gunung Palangka Gading dan satuan piroklastik Toba 2. Sayatan ini merupakan sayatan paling utara dari daerah penelitian. Anomali maksimal pada sayatan ini bernilai sekitar $5 \mathrm{mgal}$. Kondisi ini dikarenakan oleh adanya massa batuan berdensitas tinggi (warna jingga kemerahan) dengan nilai $2,80-3,00 \mathrm{~g} / \mathrm{cm}^{3}$ pada koordinat $\mathrm{X}$ antara 492 sampai 499 yang dimulai pada kedalaman $Z>2 \mathrm{~km}$. Diduga batuan ini merupakan batuan beku intrusi yang telah membeku namun masih memiliki sisa panas. Anomali negatif rendah tidak terlalu kontras. Kondisi ini dikarenakan oleh adanya persebaran massa batuan berdensitas rendah (warna biru muda) dengan nilai $2,15-2,25 \mathrm{~g} / \mathrm{cm}^{3}$ di beberapa tempat dari permukaan hingga kedalaman $Z=1 \mathrm{~km}$. Hal ini diduga sebagai respon dari beberapa sesar diperkirakan yang tersebar di sekitar utara mata air panas Sipoholon.

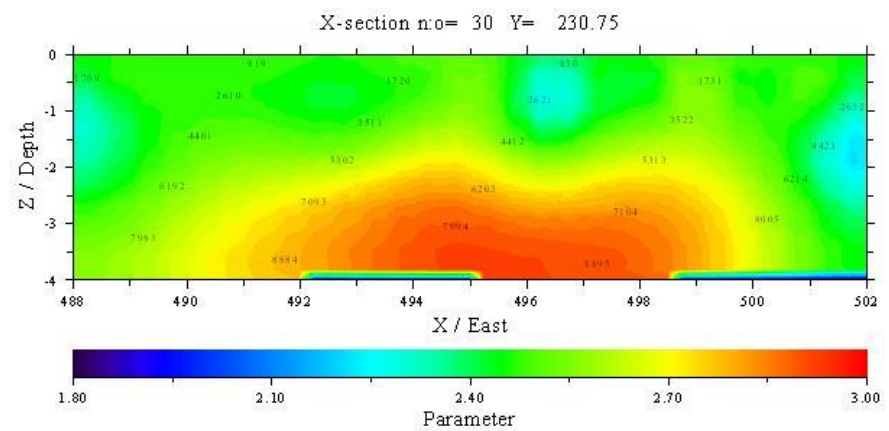

Gambar 7. Penampang model 2D lintasan E-E'

Hasil pemodelan juga diinterpretasi secara 3D (Gambar 8).
Model densitas 3D tersebut menunjukkan batuan dengan densitas rendah tersebar tidak terlalu jauh (maksimal 1,5 km) di bawah permukaan, sedangkan batuan dengan densitas tinggi tersebar dan berkelompok-kelompok di beberapa tempat mulai pada kedalaman $>1,5 \mathrm{~km}$. Batuan berdensitas tinggi dengan nilai $2,80-3,00 \mathrm{~g} / \mathrm{cm}^{3}$ di bagian selatan dan timur terlihat muncul menerobos dari bawah hingga hingga kedalaman $2 \mathrm{~km}$. Batuan ini diinterpretasikan sebagai batuan beku intrusif yang diperkirakan berperan sebagai sumber panas pada sistem panas bumi di daerah penelitian ini. Sedangkan batuan berdensitas rendah dengan nilai $2,0-2,3 \mathrm{~g} / \mathrm{cm}^{3}$ juga ditemukan di beberapa tempat dekat permukaan sampai pada kedalaman $1,5 \mathrm{~km}$. Densitas rendah yang berada di sebaran mata air panas ini diperkirakan berasosiasi dengan rekahan yang membentuk zona patahan dan mengontrol munculnya beberapa mata air panas pada daerah penelitian.

\section{KESIMPULAN}

Hasil pemodelan inversi 3D data gaya berat memperlihatkan bahwa adanya blok batuan berdensitas tinggi dengan nilai antara $2,80-3,00 \mathrm{~g} / \mathrm{cm}^{3}$ yang tersebar di selatan dan timur pada kedalaman $\mathrm{Z}>2 \mathrm{~km}$. Batuan ini diinterpretasikan sebagai batuan beku intrusif dan diduga berperan sebagai sumber panas dari sistem panas bumi daerah penelitian. Selain itu, model juga menunjukkan adanya blok batuan berdensitas rendah dengan nilai antara $2,0-2,3 \mathrm{~g} / \mathrm{cm}^{3}$ yang berada di bawah mata air panas. Blok ini diinterpretasikan sebagai batuan yang berasosiasi dengan zona patahan yang berperan sebagai pengontrol munculnya manifestasi permukaan di daerah penelitian. Hasil penelitian ini dapat digunakan sebagai informasi awal dalam pembuatan model konseptual daerah penelitian.

\section{UCAPAN TERIMA KASIH}

Penulis mengucapkan terima kasih yang sebesar-besarnya kepada Pusat Sumber Daya Mineral Batubara dan Panas Bumi, Badan Geologi KESDM RI atas dukungan data gaya berat sebagai bahan penulisan artikel ini. Rasa terima kasih juga penulis sampaikan kepada Mbak Fitri Jusmi atas kesediaan waktu diskusi dalam proses pengolahan data.

\section{DAFTAR PUSTAKA}

T. Situmorang, "Penelitian Geomagnet Daerah Panas Bumi Ria-Ria Sipoholon, T arutung, Tapanuli Utara," Bandung, 2005. A. Zarkasyi, Buku Panduan Penelitian Panas Bumi. Bandung: Pusat Sumber Daya Geologi Badan Geologi Kementerian Energi dan Sumber Daya Mineral Republik Indonesia, 2015. H. Atef, A. M. S. El-Gawada, M. A. Zaherb, and K. S. I. Faraga, "The Contribution of Gravity Method in Geothermal Exploration of Southern Part of The Gulf of Suez-Sinai Region, Egypt," NRIAG J. Astron. Geophys., vol. 5, no. 1, pp. 173-185, 2016.

[4] A. Sugianto and T. Rahadinata, "Pemodelan Gaya Berat 3D 
Daerah Panas Bumi Dolok Morawa, Kabupaten Simalungun, Sumatera Utara," Bul. Sumber Daya Geol., vol. 10, no. 2, pp. 26-39, 2015.

[5] A. Djudjun, "Penyelidikan Gaya Berat Daerah Panas Bumi Sipoholon-Tarutung Kabupaten Tapanuli Utara Provinsi Sumatera Utara," Bandung, 2005.

[6] T. A. Elkins, "The Second Derivative Method of Gravity Interpretation," Geophysics, vol. 23, pp. 97-127, 1951.

[7] S. E. Hjelt, Pragmatic Inversion of Geophysical Data. Jerman:
Springer Verlag, 1992.

[8] S. C. Constable, R. L. Parker, and C. G. Constable, "Occam's Inversion: A Practical Algorithm for Generating Smooth Models from Electro-magnetic Sounding Data," Geophysics, vol. 52, no. 3, pp. 289-300, 1987.

[9] H. Grandis, Pengantar Pemodelan Inversi Geofisika. Jakarta: Himpunan Ahli Geofisika Indonesia, 2009. 